\title{
Identification of TNF- $\alpha$ and MMP-9 as potential baseline predictive serum markers of sunitinib activity in patients with renal cell carcinoma using a human cytokine array
}

\author{
JL Perez-Gracia*,1,9, C Prior, ${ }^{2,9}$, F Guillén-Grima ${ }^{3}$, V Segura ${ }^{4}$, A Gonzalez ${ }^{5}$, A Panizo ${ }^{6}$, I Melero ${ }^{7}$, \\ E Grande-Pulido ${ }^{8}$, A Gurpide', I Gil-Bazo' and A Calvo ${ }^{2}$
}

'Department of Medical Oncology, University Clinic of Navarra, University of Navarra, Pamplona, Spain; ${ }^{2}$ Division of Oncology, CIMA, University of Navarra, Pamplona, Spain; ${ }^{3}$ Department of Preventive Medicine, University Clinic of Navarra, University of Navarra, Pamplona, Spain; ${ }^{4}$ Genomics, Proteomics and Bioinformatics Unit, CIMA. University of Navarra, Pamplona, Spain; ${ }^{5}$ Department of Biochemistry, University Clinic of Navarra, University of Navarra, Pamplona, Spain; ${ }^{6}$ Department of Pathology, University Clinic of Navarra, University of Navarra, Pamplona, Spain; ' Department of Internal Medicine, University Clinic of Navarra and CIMA, University of Navarra, Pamplona, Spain; ${ }^{8}$ Department of Medical Oncology, Pfizer Inc., Madrid, Spain

\begin{abstract}
BACKGROUND: Several drugs are available to treat metastatic renal-cell carcinoma (MRCC), and predictive markers to identify the most adequate treatment for each patient are needed. Our objective was to identify potential predictive markers of sunitinib activity in MRCC.

METHODS: We collected sequential serum samples from 31 patients treated with sunitinib. Sera of six patients with extreme phenotypes of either marked responses or clear progressions were analysed with a Human Cytokine Array which evaluates 174 cytokines before and after treatment. Variations in cytokine signal intensity were compared between both groups and the most relevant cytokines were assessed by ELISA in all the patients.

RESULTS: Twenty-seven of the 174 cytokines varied significantly between both groups. Five of them (TNF- $\alpha$, MMP-9, ICAM- I, BDNF and SDF-I) were assessed by ELISA in 21 evaluable patients. TNF- $\alpha$ and MMP-9 baseline levels were significantly increased in nonresponders and significantly associated with reduced overall survival and time-to-progression, respectively. The area under the ROC curves for TNF- $\alpha$ and MMP-9 as predictive markers of sunitinib activity were 0.83 and 0.77 .

CONCLUSION: Baseline levels of TNF- $\alpha$ and MMP-9 warrant further study as predictive markers of sunitinib activity in MRCC. Selection of patients with extreme phenotypes seems a valid method to identify potential predictive factors of response.

British Journal of Cancer (2009) I OI, I876- I883. doi:I0.1038/sj.bjc.6605409 www.bjcancer.com

Published online 10 November 2009

(C) 2009 Cancer Research UK
\end{abstract}

Keywords: sunitinib; renal cell carcinoma; TNF- $\alpha$; MMP-9; selection of extreme phenotypes

Treatment of metastatic renal cell carcinoma (MRCC) has rapidly evolved during the past years, with the development of several new targeted agents. Sunitinib (Sutent; Pfizer Inc., New York, NY, USA) and the combination of bevacizumab and interferon have shown superiority over single-agent interferon in randomized phase III trials as first-line treatment of MRCC (Motzer et al, 2007; Escudier et al, 2007b; Rini et al, 2008a). Temsirolimus was also superior to interferon in patients with poor prognosis MRCC (Hudes et al, 2007). Finally, sorafenib and everolimus have also shown efficacy in the second-line setting (Escudier et al, 2007a; Motzer et al, 2008b). Even though clinical algorithms that recommend the most appropriate agent according to each clinical

*Correspondence: Dr JL Perez Gracia, Department of Oncology, University Clinic of Navarra, University of Navarra, Avda. Pio Xll, 36, 31008, Pamplona, Spain; E-mail: jlgracia@unav.es

Presented in part in the 27th Annual Meeting of the American Society of Clinical Oncology (29 May to 2 June 2009, Orlando, FL).

${ }^{9}$ These authors equally contributed to this work.

Received I October 2009; accepted 8 October 2009; published online I0 November 2009 situation and previous treatments have been developed (Motzer et al, 2008c), predictive markers of activity to determine the most appropriate treatment for each patient are urgently needed to maximise the clinical benefit and to spare unnecessary toxicities and costs.

Selection of predictive markers of response is an intricate task, given the large number of potential targets to analyse. Highthroughput techniques have the advantage of being able to evaluate several molecular factors at one time, but their interpretation and their translation into clinical practice is somewhat cumbersome. The selection and study of individuals with very characteristic and clinically relevant phenotypes has been proposed as a methodology that may help to characterize the factors underlying such phenotypes (Perez-Gracia et al, 2002). This strategy consists of selecting and screening with highthroughput techniques of those patients presenting the most informative clinical features, rather than whole unselected series of patients, to improve the probability of finding factors that might be linked with such phenotypes. We employed this methodology to identify potential predictive factors of response to sunitinib in MRCC. 


\section{MATERIALS AND METHODS}

From November 2004 to October 2006, we obtained sequential serum samples from 31 consecutive patients with MRCC treated with sunitinib at our institution, while participating in the phase III sunitinib registration study (Motzer et al, 2007) and in an expanded use trial. Patients received sunitinib $(50 \mathrm{mg}$ per $24 \mathrm{~h})$ during 4 weeks followed by a 2 -week resting period between cycles. Follow-up and toxicity management were performed following the study protocol. Response was evaluated every two cycles using RECIST criteria (Therasse et al, 2000). Blood samples were obtained from patients at baseline and at the moment of first evaluation of response at the end of the second cycle (day 28). Serum was obtained after blood centrifugation at 1500 r.p.m. for $10 \mathrm{~min}$ at $4^{\circ} \mathrm{C}$. Samples were aliquoted and stored at $-80^{\circ} \mathrm{C}$. Both trials, as well as the protocol to obtain blood samples were approved by our institution's Ethics Committee, and all patients signed the respective informed consents.

The methodology of extreme phenotype selection was used for this study (Perez-Gracia et al, 2002). Three patients with very marked clinical responses to sunitinib and three with clear progressions, despite adequate performance status, absence of comorbidities and correct treatment administration, were selected by the attending clinicians. Sera were analysed with a cytokine array that is described below. The most relevant candidate cytokines, in terms of statistical significance and biological plausibility, were selected and they were assessed in the rest of the patients using ELISA.

\section{High-throughput serum cytokine assay}

In a first set of experiments we sought to identify serum cytokines that were modulated by sunitinib in MRCC patients. A Human Cytokine Antibody Array (Series 2000, RayBiotech, Norcross, GA, USA), which has been clinically validated (Ray et al, 2007), was used to analyse 174 human cytokines related to angiogenesis, immunity and tumour proliferation pathways (the complete list of cytokines is available as Supplementary Material, Appendix 1). Sera of three patients with an excellent response to sunitinib and of three non-responders were analysed with the array. The baseline cytokine array profile was compared with that found after treatment for each patient. Samples were analysed according to the manufacturer's instructions. Briefly, wells of the microarray glass slides were blocked in blocking buffer for $30 \mathrm{~min}$ and subsequently incubated with 1:5 diluted samples ( $90 \mu \mathrm{l}$ per well) overnight at $4^{\circ} \mathrm{C}$. Slides were washed in washing buffer and incubated with a biotin-conjugated cocktail of antibodies for $2 \mathrm{~h}$. After further washing, horseradish peroxidase (HRP)-conjugated streptavidin was incubated for $2 \mathrm{~h}$. To visualise bound antibodies, samples were incubated with Alexa flour 555-conjugated streptavidin in darkness for $2 \mathrm{~h}$. Detection of signals was assessed with a GMS 418 array scanner (Genetic Microsystems, Woburn, MA, USA). Spots signal intensities were imported into a GMS array scanner programme for analysis.

\section{Array data normalisation and analysis}

Positive control signals on each array were used as normalization factor following the manufacturer's instructions. For each cytokine, baseline intensity levels were compared with those found after treatment and fold-change differences were calculated. Global loess-based normalization was performed using Bioconductor (Gentleman et al, 2004) and ratios were scaled based on the median absolute deviation. Filtering of flat profiles was applied using a variation coefficient value of 0.5 . Statistical comparison of the two experimental conditions was performed using the Wilcoxon test, and the obtained $P$-value was corrected for multiple hypotheses testing using the False Discovery Rate (FDR) method for array analysis. The FDR of a test is defined as the expected proportion of false positives among the declared significant results (Benjamini and Hochberg, 1995, 2000; Keselman et al, 2002). The selection of cytokines for ELISA validation was based on an FDR threshold of 10\% (Storey and Tibshirani, 2003).

\section{ELISA}

Serum samples obtained at baseline and at the moment of response evaluation were assayed by ELISA (RayBiotech), following the manufacturer's protocol, for TNF- $\alpha$, MMP-9, ICAM-1, BDNF, VEGF, and SDF-1. Briefly, 96-well plates were incubated at $4^{\circ} \mathrm{C}$ overnight with standards at different concentrations, and serum samples. After several washes, wells were incubated with biotinylated antibodies for $1 \mathrm{~h}$, followed by HRP-conjugated streptavidin for $45 \mathrm{~min}$. Enzymatic reactions were developed and the absorbance was measured at $450 \mathrm{~nm}\left(\mathrm{~A}_{450}\right)$ in a SunRise (Tecan, Salzburg, Austria) ELISA plate reader. Protein levels were calculated according to standard curves.

\section{Statistical methods}

Array data was analysed as described above. Statistical differences between groups were examined using the Student's $t$-test for unpaired and paired data for parametric variables, and the Mann-Whitney $U$-test for unpaired non-parametric variables. The Wilcoxon test was used to study paired non-parametric variables. Normality was tested using Shapiro-Wilks Test. Data were analysed with the SPSS statistical software (version 15.0 for Windows SPSS). $P$-values $<0.05$ were considered significant and $95 \%$ confidence intervals were calculated. Time-to-event variables were assayed with the Kaplan-Meier test. Survival curves were compared with the Log-rank test. Risk of lack of response was measured by exact logistic regression (pack logXact V.8). Sensitivity, specificity, predictive values, and receiver operator characteristic (ROC) curves, as well as their confidence intervals were computed with Epitable from Epiinfo v6.1. Discriminant function analysis and Cox regression were performed with SPSS.

\section{RESULTS}

Variations in serum levels of 27 cytokines from the array showed significant differences between responders and non-responders

Twenty-seven of the 174 cytokines assayed by the array were able to cluster the patients in two different groups and to discriminate those with marked clinical responses $(n=3)$ from those with clear disease progression $(n=3)$, according to the FDR method for array analysis, using a threshold of $10 \%$ (Figure 1). Levels of cytokines such as matrix metalloproteinase-9 (MMP-9), tumour necrosis factor- $\alpha$ (TNF- $\alpha$ ) and brain-derived neurotrophic factor (BDNF) increased exclusively in non-responding patients, as compared with responders. Conversely, other soluble proteins such as intercellular adhesion molecule-1 (ICAM-1), macrophage inflammatory protein $3 \beta$, stromal cell-derived factor-1 (SDF-1) and interleukin-17 decreased significantly only in non-responders and either did not change or were increased in responders.

\section{Baseline levels of MMP-9 and TNF- $\alpha$ predict clinical benefit of sunitinib}

From the 27 cytokines modulated by sunitinib identified by the cytokine array, five (TNF- $\alpha$, MMP-9, ICAM-1, BDNF, and SDF-1) were selected for further quantitative analysis by ELISA in the whole patient series, based on statistical significance and on biological plausibility of the involvement of such cytokines in renal cell carcinoma. TNF- $\alpha$ was selected because recent reports have 
Table I Patient characteristics

\begin{tabular}{lc}
\hline Characteristics & N (\%) \\
\hline Sex & \\
Male & $23(74)$ \\
Female & $8(26)$ \\
Age & \\
Median & 58 \\
Range & $40-83$ \\
& \\
Performance status & \\
0 & $20(64)$ \\
I & $10(34)$ \\
2 & $1(2)$ \\
Tumour histology & \\
Clear-cell carcinoma & \\
Response to sunitinib & $31(100)$ \\
Partial response & \\
Stable disease & $13(42)$ \\
Progression & $4(13)$ \\
Previous treatment lines & $14(45)$ \\
None & \\
I & \\
2 & $13(42)$ \\
$\geqslant 3$ & $11(35)$ \\
Previous treatments & $3(10)$ \\
Low-dose cytokines & $4(13)$ \\
Bevacizumab & \\
Other & $15(48)$ \\
\hline & $6(19)$ \\
\hline & $5(16)$ \\
\hline
\end{tabular}

84.7); Sp: 75\% (95\% CI: 42.8 - 93.3); PPV: 62.5 (95\% CI: 25.9-89.8); NPV: 69.2 (95\% CI: $38.9-89.6)$. For TNF- $\alpha$, using the median $(50$ $\left.\mathrm{pg} \mathrm{ml}^{-1}\right)$ as a cutoff value, the following results were obtained: $\mathrm{S}$ : 88\% (95\% CI: 50.7-99.4); Sp: 75\% (95\% CI: 42.8-93.3); PPV 72.7\% (95\% CI: 39.3 -92.7); NPV: 90\% (95\% CI: 54.1-99.5). Areas under the ROC curves for TNF- $\alpha$ and MMP-9 were 0.828 and 0.768 , respectively.

Exact logistic regression showed that increasing MMP-9 levels were associated with a significant increase in the risk of no response $(\mathrm{OR}=2.84 ; 95 \% \mathrm{CI}: 1.11-10.44, P=0.024)$, whereas TNF- $\alpha$ levels did not show such association. A stepwise discriminant function analysis further revealed that MMP-9 levels are better predictors of clinical benefit than TNF- $\alpha$ levels. The discriminant model showed that MMP-9 levels over $4062 \mathrm{ng} \mathrm{ml}^{-1}$ significantly $(P=0.027)$ predicted sunitinib's lack of clinical benefit (Wilk's $\lambda=0.767 ; \chi^{2}=4.913$ ).

\section{Baseline levels of MMP-9 and TNF- $\alpha$ are associated with survival}

Median time-to-progression (TTP) for the whole group of patients was 7.03 months (95\% CI: $5.51-8.55$ ) (Figure $3 \mathrm{~A}$ ) and median overall survival (OS) was 11.27 months (95\% CI: 4.88-17.65) (Figure 3B). Median OS of patients with TNF- $\alpha$ baseline levels above the median $\left(50 \mathrm{pg} \mathrm{ml}^{-1}\right.$ ) was 7 months (s.d.: $1.491 ; 95 \% \mathrm{CI}$ : 4.078-9.92), as compared with 20 months (s.d.: $6.803 ; 95 \%$ CI: $6.65-33.34, P=0.045$ ) for the other patients (Figure 3C). A significant association between TNF- $\alpha$ levels higher than $50 \mathrm{pg} \mathrm{ml}^{-1}$ and reduced OS was found $(P=0.045)$. TTP correlation with baseline TNF- $\alpha$ levels, approached, but did not reach statistical significance $(P=0.07)$. For MMP-9, using the median as a cutoff value, no differences were observed. However, levels above the upper tercile $\left(4062 \mathrm{ng} \mathrm{ml}^{-1}\right)$ showed a significant 

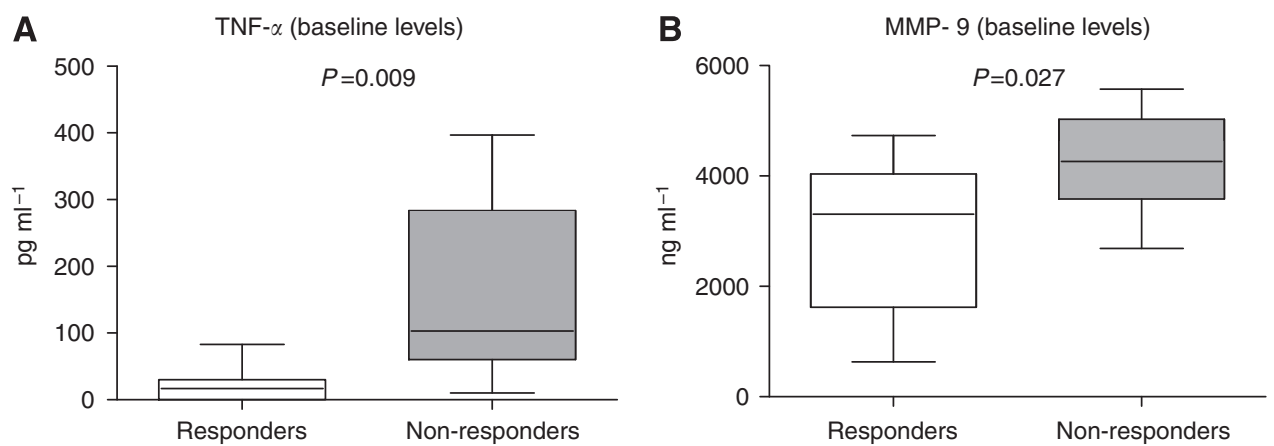

Figure 2 Determination by ELISA of serum baseline levels of TNF- $\alpha(\mathbf{A})$ and MMP-9 (B) in MRCC patients treated with sunitinib. Inbox bars show median levels for each cytokine of each group of patients. (TNF- $\alpha$ : $20 \mathrm{pg} \mathrm{ml} \mathrm{f}^{-1}$ for responders, and $103.3 \mathrm{pg} \mathrm{ml}^{-1}$ for non-responders; MMP-9: $3303.9 \mathrm{ng} \mathrm{ml}{ }^{-1}$ for responders, and $4262.4 \mathrm{ng} \mathrm{ml}^{-1}$ for non-responders). A significant increase in non-responders compared with responders is found.

Table 2 Statistical comparison of mean baseline cytokine levels quantified by ELISA between patients presenting clinical benefit or progression

\begin{tabular}{|c|c|c|c|}
\hline Cytokines & Clinical benefit (mean \pm s.d) & Progression (mean \pm s.d.) & $P$-value \\
\hline
\end{tabular}

Bold values are statistically significant.

association with reduced TTP $(P=0.042)$. Patients with MMP-9 levels above that value had a median TTP of 3 months (s.d.: 0.598 ; 95\% CI: $1.83-4.17$ ) as compared with 8 months (s.d.: 1.88; 95\% CI: 4.33-11.67) for patients below that limit (Figure 3D). No association was observed between MMP-9 baseline levels and OS $(P=0.515)$.

Cox-regression analysis showed a significant interaction between both MMP-9 and TNF- $\alpha$ levels in predicting the risk of reduced TTP: HR for the interaction was 10.323 (95\% CI: $1.028-$ 103.64, $P<0.047$ ), whereas HR for TNF- $\alpha$ alone was 2.63 (95\% CI: $0.986-7.058, P=0.053)$ and for MMP-9 alone, 3.05 (95\% CI: 1.09 $8.51, P=0.033)$.

\section{MMP-9, SDF-1, and BDNF serum levels are modulated by sunitinib}

Baseline levels of the cytokines quantified by ELISA were compared with those measured at the moment of response evaluation. MMP-9, SDF-1, and BDNF levels significantly changed upon treatment (Figure 4), whereas TNF- $\alpha$, VEGF, and ICAM-1 did not vary. Sunitinib significantly decreased MMP-9 levels in both patient groups $(P=0.011$ for patients with clinical benefit, and $P=0.005$ for patients with progression). BDNF levels also decreased in both groups $(P=0.016$ and $P=0.011$, respectively). On the contrary, SDF-1 levels increased significantly $(P<0.004)$ in patients presenting clinical benefit, whereas in patients who progressed, the increment approached statistical significance $(P=0.08$, Figure 4). Therefore, MMP-9, SDF-1, and BDNF seem novel cytokines modulated by sunitinib.

\section{DISCUSSION}

Several new agents are available for treatment of MRCC and many others are under clinical development, leading to a situation in which the choice of the optimal therapy for each patient is sometimes unclear. Predictive markers of clinical benefit are needed to select the most appropriate treatment for each patient.
In an attempt to improve the yield of our study, we selected patients with phenotypes of either marked responses or clear progressions and we screened their serum samples with a protein array assessing 174 cytokines. This allowed us to select the cytokines that significantly clustered both groups of patients. Quantitative analysis by ELISA of those cytokines in the entire group of patients confirmed that TNF- $\alpha$ and MMP-9 baseline levels were significantly higher in non-responders. In addition, the area under the ROC curves of TNF- $\alpha$ and MMP-9 indicated good accuracy for both markers as predictive factors of sunitinib clinical benefit. These results suggest that baseline serum levels of TNF- $\alpha$ and MMP-9 warrant further evaluation in future studies as predictive markers of sunitinib activity in patients with MRCC. Our study also supports that our methodological approach seems useful to select candidate predictive factors of clinical benefit of a determined treatment, and that it can reveal alternative pathways that might be relevant to understand the drug's mechanism of action.

Metalloproteinase-9 (MMP-9) belongs to the family of matrix metalloproteases and has a key role in promoting angiogenesis and metastasis (Bergers et al, 2000). In the bone marrow, VEGF and SDF-1-mediated activation of MMP-9 releases soluble Kit-ligand, permitting the mobilisation of endothelial and hematopoietic stem cells (Heissig et al, 2002). Elevated serum levels of MMP-9 are associated with tumour invasion and metastatic spread in a variety of malignancies. Serum levels and tissue expression of MMP-9 are higher in renal cell carcinoma as compared with healthy controls (Lein et al, 2000). Tissue MMP-9 levels in renal cell carcinoma samples are strongly associated with high nuclear grade (Kawata et al, 2007) and shortened survival (Kallakury et al, 2001).

Pathological regulation of TNF- $\alpha$ has been related to primary and metastatic cancer promotion, directly or via a complex network of cytokines, chemokines, and matrix metalloproteases (Kulbe et al, 2007). TNF- $\alpha$ can be secreted by immune-related cells and tumour cells, and it has been suggested to act in an autocrine/ paracrine way to promote cancer development (Harrison et al, 2007). Both TNF- $\alpha$ and its receptors are coexpressed by renal carcinoma cells and, upon binding, the expression of angiogenesis- 

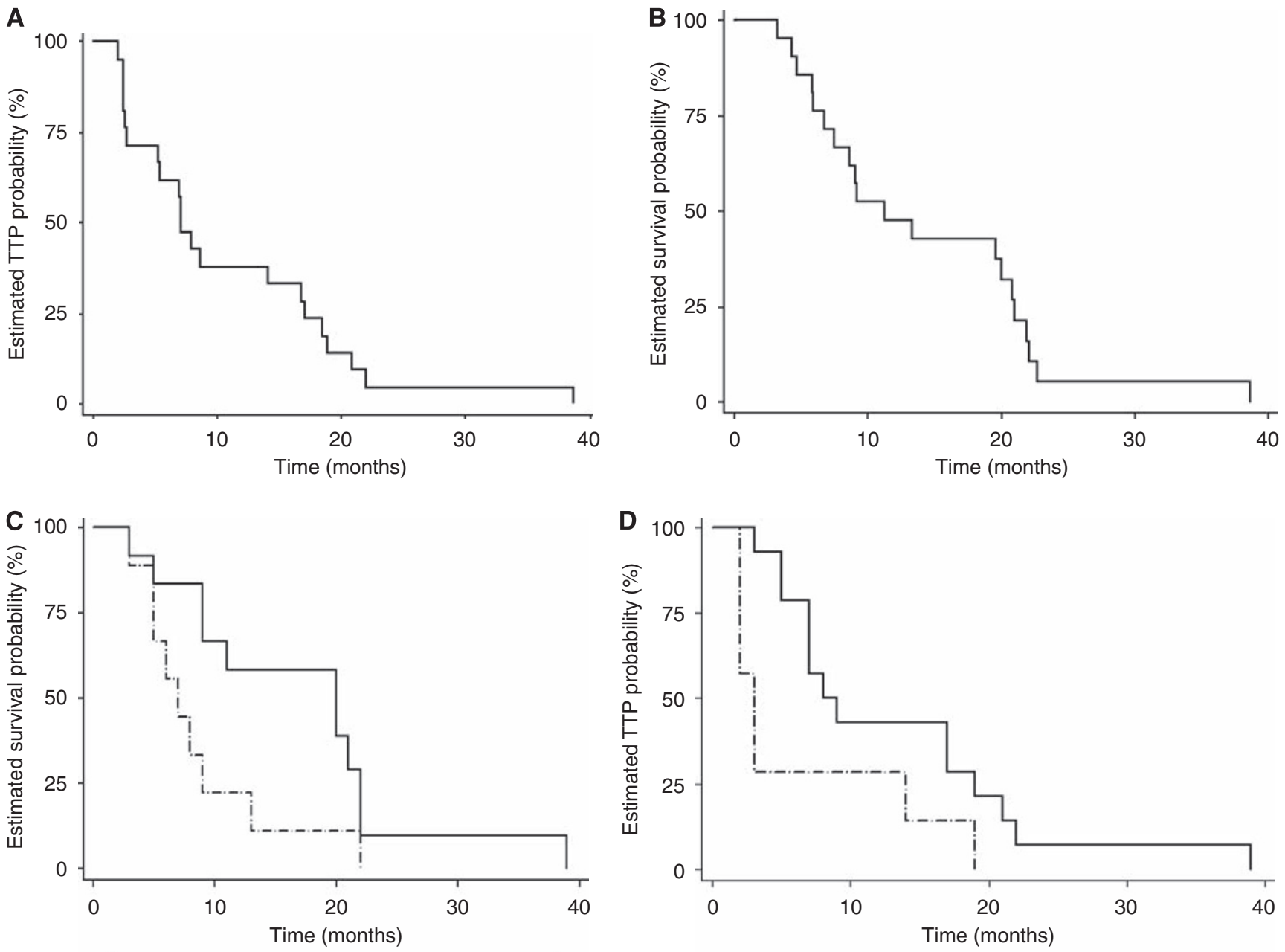

— Lower median TNF $\alpha$-.-.--- Upper median TNF $\alpha$

— Lower terciles MMP-9 _-.--- Upper tercile MMP-9

Figure 3 Kaplan-Meier plots of time-to-progression $(\mathbf{A})$ and overall survival $(\mathbf{B})$ in the complete group. Baseline levels of TNF- $\alpha$ above the median are significantly associated $(P=0.045)$ with reduced overall survival $(\mathbf{C})$. MMP-9 levels over the upper tercile are significantly associated $(P=0.042)$ with decreased time-to-progression (D).

related genes such as VEGF (Yoshida et al, 1997) and IL-6 has been reported ( $\mathrm{Ng}$ et al, 1994). The potential involvement of TNF- $\alpha$ in renal cancer has been recently demonstrated. High affinity antibodies that target TNF- $\alpha$, preventing its binding to TNF- $\alpha \mathrm{R} 1$ and R2 receptors are clinically available for treatment of rheumatoid arthritis and Crohn's disease. Such antibodies have also been tested as treatment for MRCC at standard and high doses in 37 patients, producing partial responses in three patients $(8 \%)$ and stabilizations in 11 patients $(30 \%)$ (Harrison et al, 2007). They also reported that baseline TNF- $\alpha$ levels were predictive of clinical benefit. These results along with ours highlight the potential role of TNF- $\alpha$ as a biomarker in MRCC and support the possibility of combining sunitinib with TNF- $\alpha$ blocking therapies.

We have also identified by high-throughput analysis that SDF-1 and BDNF are modulated by sunitinib. SDF-1 is secreted by carcinoma-associated fibroblasts and stimulates cancer cell growth directly through the CXCR4 receptor expressed on tumour cells, and also recruits endothelial progenitor cells into tumours, thereby fostering neoangiogenesis (Orimo and Weinberg, 2006). The SDF-1/CXCR4 pathway has been suggested as a target for renal cancer therapy (Reckamp et al, 2008), and dosedependent increases in SDF-1 levels have been reported previously in normal nontumour-bearing mice treated with sunitinib in a previous study (Ebos et al, 2007), which further supports our results. BDNF is a novel angiogenic factor that upregulates MMP-2 and MMP-9 and promotes their activation (Sun et al, 2006). Interestingly, anti-BDNF antibodies in multiple myeloma models produce inhibition of tumour growth and angiogenesis (Hu et al, 2007). Expression of the BDNF receptor (TrkB) in Wilm's tumours is associated with poor prognosis, probably because it provides autocrine growth-stimulating signals (Eggert et al, 2001). BDNF/TrkB should be considered in future studies to assess its potential role as a biomarker and therapeutical target in renal carcinoma.

Other studies have evaluated different potential biomarkers of sunitinib activity. HIF $\alpha$ and $2 \alpha$ levels in cell lines and in human tumours have been shown to correlate with clinical response to sunitinib in patients with MRCC (Patel et al, 2008). Low baseline levels of sVEGFR-3 and VEGF-C have been associated with a longer TTP and an improved response rate (Rini et al, 2008b). Other investigators have reported that patients with gastrointestinal stromal tumours that showed clinical benefit with sunitinib had a reduced number of circulating endothelial cells and monocytes, as compared with patients who did not respond (Norden-Zfoni et al, 2007). Greater variations in VEGF, sVEGFR-2, and s-VEGFR-3 were 


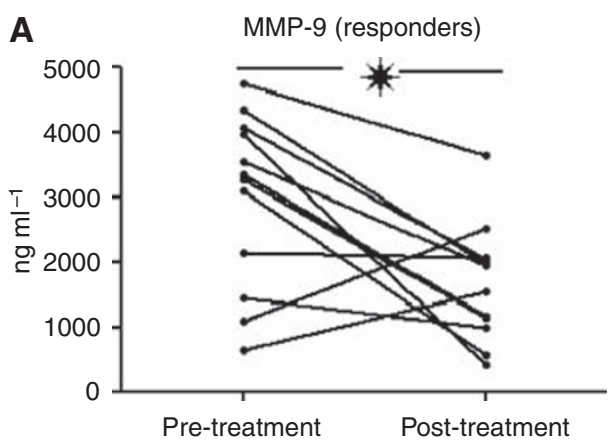

$\mathbf{B}$

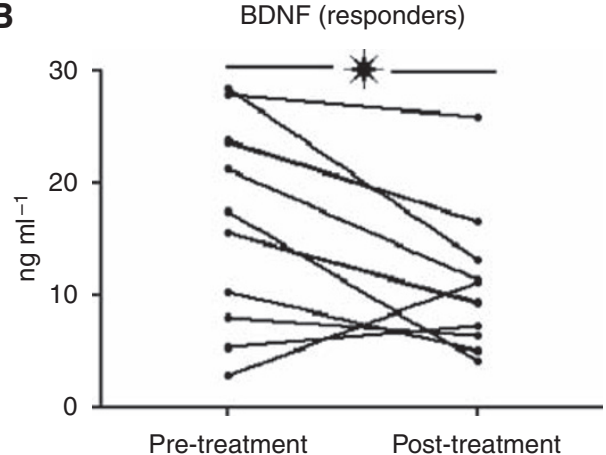

C

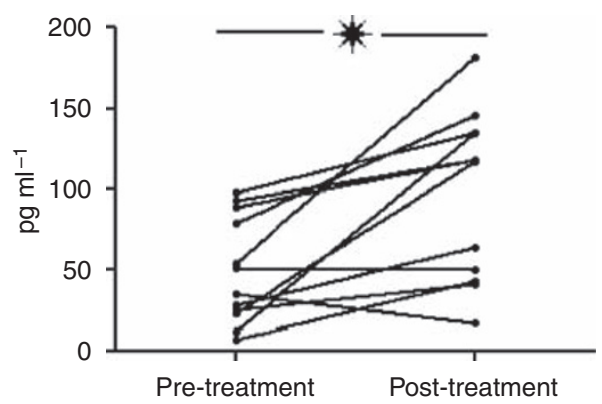

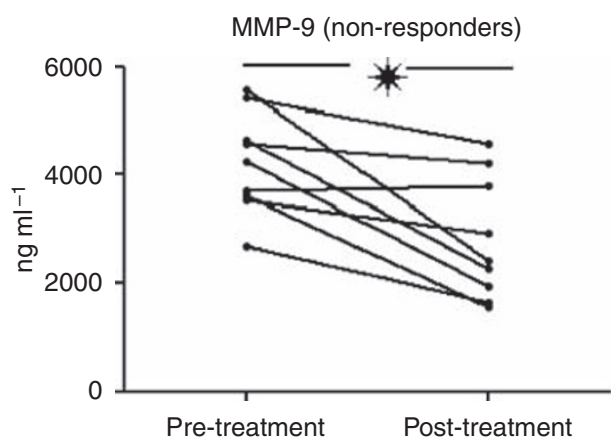

BDNF (non-responders)

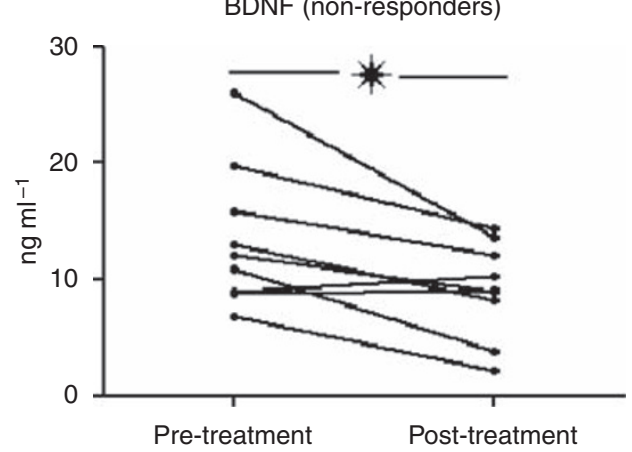

SDF-1 (non-responders)

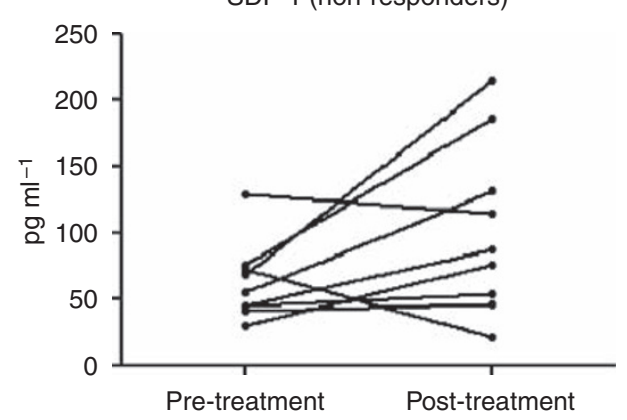

Figure 4 Sunitinib modulates serum levels of MMP-9 (A) BDNF (B), and SDF-I (C). Both MMP-9 and BDNF levels are reduced by sunitinib, whereas treatment increases SDF-I levels. $* P<0.05$.

observed in patients presenting objective tumour responses than in patients with stable disease or progression (Deprimo et al, 2007). Finally, some clinical factors have been evaluated as predictors of clinical activity. Motzer et al, (2008a) have developed a clinical nomogram that predicts the probability of a 12-month TTP in patients treated with sunitinib. Rini et al (2008c), have shown that high levels of diastolic blood pressure during treatment with axitinib, a potent and selective inhibitor of VEGFR1, 2 and 3, shows a marked correlation with survival in a series of patients with different tumours. Choueiri et al (2007) have reported that five clinical factors, - time-to-diagnosis, baseline calcium and platelet and neutrophil counts and performance status are independent prognostic factors for patients with MRCC treated with anti-VEGF therapy and have developed a prognostic model that categorizes such patients into three prognostic groups. These potential predictive factors of activity, along with those determined in our study should be assessed in prospective trials to provide a more accurate prediction of sunitinib activity.

The main limitations of our study are the lack of standardisation of current tools to determine serum TNF- $\alpha$ and MMP-9 levels as well as the limited sample size. Yet, these limitations are partially overcome by previous reports that also support a role for TNF- $\alpha$ and MMP-9 in MRCC, as reviewed above. In any case, confirmatory studies will be required to corroborate if baseline serum levels of TNF- $\alpha$ and MMP-9 are clinically useful in this setting. If so, the use of these markers might be relevant for further development of sunitinib in other tumour types. Additional research will be required to determine if the predictive value of TNF- $\alpha$ and MMP-9 is specific of sunitinib or if they can also be used to predict activity of other drugs used to treat MRCC.

In conclusion, baseline serum levels of MMP-9 and TNF- $\alpha$ merit further study as predictive markers of sunitinib activity in patients with MRCC. Extreme phenotype selection in combination with high-throughput analysis is a valid method to identify candidates who might prove to be useful predictive factors of activity in cancer treatments.

\section{ACKNOWLEDGEMENTS}

We are indebted to Mercedes Egaña, Elena Navarcorena, and Leyre Resano for collecting and processing the blood samples from all 
the patients. We also thank Drs Eva Bandres and Ana Abajo for technical support with the cytokine array technique.

\section{REFERENCES}

Benjamini Y, Hochberg Y (1995) Controlling the false discovery rate: a practical and powerful approach to multiple testing. J R Stat Soc Ser B 57: $289-300$

Benjamini Y, Hochberg Y (2000) On the adaptive control of the false discovery rate in multiple testing with independent statistics. $J E d u$ Behav Stat 25: $60-83$

Bergers G, Brekken R, McMahon G, Vu TH, Itoh T, Tamaki K, Tanzawa K, Thorpe P, Itohara S, Werb Z, Hanahan D (2000) Matrix metalloproteinase- 9 triggers the angiogenic switch during carcinogenesis. Nat Cell Biol 2: $737-744$

Choueiri TK, Garcia JA, Elson P, Khasawneh M, Usman S, Golshayan AR, Baz RC, Wood L, Rini BI, Bukowski RM (2007) Clinical factors associated with outcome in patients with metastatic clear-cell renal cell carcinoma treated with vascular endothelial growth factor-targeted therapy. Cancer 110: $543-550$

Deprimo SE, Bello CL, Smeraglia J, Baum CM, Spinella D, Rini BI, Michaelson MD, Motzer RJ (2007) Circulating protein biomarkers of pharmacodynamic activity of sunitinib in patients with metastatic renal cell carcinoma: modulation of VEGF and VEGF-related proteins. J Trans Med 5: 32

Ebos JM, Lee CR, Christensen JG, Mutsaers AJ, Kerbel RS (2007) Multiple circulating proangiogenic factors induced by sunitinib malate are tumorindependent and correlate with antitumor efficacy. Proc Natl Acad Sci USA 104: 17069 - 17074

Eggert A, Grotzer MA, Ikegaki N, Zhao H, Cnaan A, Brodeur GM, Evans AE (2001) Expression of the neurotrophin receptor TrkB is associated with unfavorable outcome in Wilms' tumor. J Clin Oncol 19: 689-696

Escudier B, Eisen T, Stadler WM, Szczylik C, Oudard S, Siebels M, Negrier S, Chevreau C, Solska E, Desai AA, Rolland F, Demkow T, Hutson TE, Gore M, Freeman S, Schwartz B, Shan M, Simantov R, Bukowski RM (2007a) Sorafenib in advanced clear-cell renal-cell carcinoma. $N$ Engl J Med 356: $125-134$

Escudier B, Pluzanska A, Koralewski P, Ravaud A, Bracarda S, Szczylik C, Chevreau C, Filipek M, Melichar B, Bajetta E, Gorbunova V, Bay JO, Bodrogi I, Jagiello-Gruszfeld A, Moore N (2007b) Bevacizumab plus interferon alfa-2a for treatment of metastatic renal cell carcinoma: a randomised, double-blind phase III trial. Lancet 370: 2103-2111

Gentleman RC, Carey VJ, Bates DM, Bolstad B, Dettling M, Dudoit S, Ellis B, Gautier L, Ge Y, Gentry J, Hornik K, Hothorn T, Huber W, Iacus S, Irizarry R, Leisch F, Li C, Maechler M, Rossini AJ, Sawitzki G, Smith C, Smyth G, Tierney L, Yang JY, Zhang J (2005) Bioconductor: open software development for computational biology and bioinformatics. Genome Biol 5: R80.

Harrison ML, Obermueller E, Maisey NR, Hoare S, Edmonds K, Li NF, Chao D, Hall K, Lee C, Timotheadou E, Charles K, Ahern R, King DM, Eisen T, Corringham R, DeWitte M, Balkwill F, Gore M (2007) Tumor necrosis factor alpha as a new target for renal cell carcinoma: two sequential phase II trials of infliximab at standard and high dose. J Clin Oncol 25: $4542-4549$

Hawinkels LJ, Zuidwijk K, Verspaget HW, de Jonge-Muller ES, van Duijn W, Ferreira V, Fontijn RD, David G, Hommes DW, Lamers CB, Sier CF (2008) VEGF release by MMP-9 mediated heparan sulphate cleavage induces colorectal cancer angiogenesis. Eur J Cancer 44: $1904-1913$

Heissig B, Hattori K, Dias S, Friedrich M, Ferris B, Hackett NR, Crystal RG, Besmer P, Lyden D, Moore MA, Werb Z, Rafii S (2002) Recruitment of stem and progenitor cells from the bone marrow niche requires MMP-9 mediated release of kit-ligand. Cell 109: 625-637

Hu Y, Wang YD, Guo T, Wei WN, Sun CY, Zhang L, Huang J (2007) Identification of brain-derived neurotrophic factor as a novel angiogenic protein in multiple myeloma. Cancer Genet Cytogenet 178: 1-10

Hudes G, Carducci M, Tomczak P, Dutcher J, Figlin R, Kapoor A, Staroslawska E, Sosman J, McDermott D, Bodrogi I, Kovacevic Z, Lesovoy V, Schmidt-Wolf IG, Barbarash O, Gokmen E, O’Toole T, Lustgarten S, Moore L, Motzer RJ (2007) Temsirolimus, interferon alfa, or both for advanced renal-cell carcinoma. $N$ Engl J Med 356: $2271-2281$
Supplementary Information accompanies the paper on British Journal of Cancer website (http://www.nature.com/bjc)

Kallakury BV, Karikehalli S, Haholu A, Sheehan CE, Azumi N, Ross IS (2001) Increased expression of matrix metalloproteinases 2 and 9 and tissue inhibitors of metalloproteinases 1 and 2 correlate with poor prognostic variables in renal cell carcinoma. Clin Cancer Res 7: $3113-3119$

Kawata N, Nagane Y, Hirakata H, Ichinose T, Okada Y, Yamaguchi K, Takahashi S (2007) Significant relationship of matrix metalloproteinase 9 with nuclear grade and prognostic impact of tissue inhibitor of metalloproteinase 2 for incidental clear cell renal cell carcinoma. Urology 69: $1049-1053$

Keselman HJ, Cribbie R, Holland B (2002) Controlling the rate of Type I error over a large set of statistical tests. Br J Math Stat Psychol 55: $27-39$

Kulbe H, Thompson R, Wilson JL, Robinson S, Hagemann T, Fatah R, Gould D, Ayhan A, Balkwill F (2007) The inflammatory cytokine tumor necrosis factor-alpha generates an autocrine tumor-promoting network in epithelial ovarian cancer cells. Cancer Res 67: 585-592

Lein M, Jung $\mathrm{K}$, Laube C, Hubner T, Winkelmann B, Stephan C, Hauptmann S, Rudolph B, Schnorr D, Loening SA (2000) Matrixmetalloproteinases and their inhibitors in plasma and tumor tissue of patients with renal cell carcinoma. Int I Cancer 85: 801-804

Motzer RJ, Bukowski RM, Figlin RA, Hutson TE, Michaelson MD, Kim ST, Baum CM, Kattan MW (2008a) Prognostic nomogram for sunitinib in patients with metastatic renal cell carcinoma. Cancer 113: 1552- 1558

Motzer RJ, Escudier B, Oudard S, Hutson TE, Porta C, Bracarda S, Grunwald V, Thompson JA, Figlin RA, Hollaender N, Urbanowitz G, Berg WJ, Kay A, Lebwohl D, Ravaud A (2008b) Efficacy of everolimus in advanced renal cell carcinoma: a double-blind, randomised, placebo-controlled phase III trial. Lancet 372: 449-456

Motzer RJ, Escudier B, Oudard S, Porta C, Hutson TE, Bracarda S, Hollaender N, Urbanowitz G, Kay A, Ravaud A (2008c) RAD001 vs placebo in patients with metastatic renal cell carcinoma (RCC)after progression on VEGFr-TKI therapy: Results from a randomized, doubleblind, multicenter Phase-III study. J Clin Oncol (Meeting Abstracts) 26: LBA5026

Motzer RJ, Hutson TE, Tomczak P, Michaelson MD, Bukowski RM, Rixe O, Oudard S, Negrier S, Szczylik C, Kim ST, Chen I, Bycott PW, Baum CM, Figlin RA (2007) Sunitinib versus interferon alfa in metastatic renal-cell carcinoma. $N$ Engl J Med 356: 115 - 124

Ng SB, Tan YH, Guy GR (1994) Differential induction of the interleukin-6 gene by tumor necrosis factor and interleukin-1. J Biol Chem 269: $19021-19027$

Norden-Zfoni A, Desai J, Manola J, Beaudry P, Force J, Maki R, Folkman J, Bello C, Baum C, DePrimo SE, Shalinsky DR, Demetri GD, Heymach JV (2007) Blood-based biomarkers of SU11248 activity and clinical outcome in patients with metastatic imatinib-resistant gastrointestinal stromal tumor. Clin Cancer Res 13: 2643-2650

Orimo A, Weinberg RA (2006) Stromal fibroblasts in cancer: a novel tumor-promoting cell type. Cell Cycle 5: 1597-1601

Patel PH, Chadalavada RS, Ishill NM, Patil S, Reuter VE, Motzer RJ, Chaganti RS (2008) Hypoxia-inducible factor (HIF) $1\{$ alpha\} and 2 alpha\} levels in cell lines and human tumor predicts response to sunitinib in renal cell carcinoma (RCC). I Clin Oncol (Meet Abstr) 26: 5008

Perez-Gracia JL, Gloria Ruiz-Ilundain M, Garcia-Ribas I, Maria Carrasco E (2002) The role of extreme phenotype selection studies in the identification of clinically relevant genotypes in cancer research. Cancer 95: $1605-1610$

Ramaswamy B, Elias AD, Kelbick NT, Dodley A, Morrow M, Hauger M, Allen J, Rhoades C, Kendra K, Chen HX, Eckhardt SG, Shapiro CL (2006) Phase II trial of bevacizumab in combination with weekly docetaxel in metastatic breast cancer patients. Clin Cancer Res 12: $3124-3129$

Ray S, Britschgi M, Herbert C, Takeda-Uchimura Y, Boxer A, Blennow K, Friedman LF, Galasko DR, Jutel M, Karydas A, Kaye JA, Leszek J, Miller BL, Minthon L, Quinn JF, Rabinovici GD, Robinson WH, Sabbagh MN So YT, Sparks DL, Tabaton M, Tinklenberg J, Yesavage JA, Tibshirani R, 
Wyss-Coray $\mathrm{T}$ (2007) Classification and prediction of clinical Alzheimer's diagnosis based on plasma signaling proteins. Nat Med 13: $1359-1362$

Reckamp KL, Strieter RM, Figlin RA (2008) Chemokines as therapeutic targets in renal cell carcinoma. Expert Rev Anticancer Ther 8: 887-893

Rini BI, Halabi S, Rosenberg JE, Stadler WM, Vaena DA, Ou SS, Archer L, Atkins JN, Picus J, Czaykowski P, Dutcher J, Small EJ (2008a) Bevacizumab plus interferon alfa compared with interferon alfa monotherapy in patients with metastatic renal cell carcinoma: CALGB 90206. J Clin Oncol 26: $5422-5428$

Rini BI, Michaelson MD, Rosenberg JE, Bukowski RM, Sosman JA, Stadler WM, Hutson TE, Margolin K, Harmon CS, DePrimo SE, Kim ST, Chen I, George DJ (2008b) Antitumor activity and biomarker analysis of sunitinib in patients with bevacizumab-refractory metastatic renal cell carcinoma. J Clin Oncol 26: 3743-3748

Rini BI, Schiller JH, Fruehauf JP, Cohen EE, Tarazi JC, Rosbrook B, Ricart AD, Olszanski AJ, Kim S, Spano J (2008) Association of diastolic blood pressure $(\mathrm{dBP}) \geqslant 90 \mathrm{mmHg}$ with overall survival $(\mathrm{OS})$ in patients treated with axitinib (AG- 013736). J Clin Oncol (Meet Abstr) 26: 3543

Storey JD, Tibshirani R (2003) Statistical significance for genomewide studies. Proc Natl Acad Sci USA 100: 9440 - 9445

Sun CY, Hu Y, Wang HF, He WJ, Wang YD, Wu T (2006) Brain-derived neurotrophic factor inducing angiogenesis through modulation of matrix-degrading proteases. Chin Med J (England) 119: 589-595

Therasse P, Arbuck SG, Eisenhauer EA, Wanders J, Kaplan RS, Rubinstein L, Verweij J, Van Glabbeke M, van Oosterom AT, Christian MC, Gwyther SG (2000) New guidelines to evaluate the response to treatment in solid tumors. European Organization for Research and Treatment of Cancer, National Cancer Institute of the United States, National Cancer Institute of Canada. J Natl Cancer Inst 92: 205-216

Yoshida S, Ono M, Shono T, Izumi H, Ishibashi T, Suzuki H, Kuwano M (1997) Involvement of interleukin-8, vascular endothelial growth factor, and basic fibroblast growth factor in tumor necrosis factor alphadependent angiogenesis. Mol Cell Biol 17: 4015-4023 